\title{
THE FORMATION OF DELUVIAL AND ALLUVIAL CONES AS A CONSEQUENCE OF HUMAN SETTLEMENT ON A LOESS PLATEAU: AN EXAMPLE FROM THE CHROBERZ AREA (POLAND)
}

\author{
Piotr Szwarczewski \\ Department of Geomorphology, Faculty of Geography and Regional Studies, University of Warsaw, Krakowskie Przed- \\ mieście 30, 00-927 Warsaw, Poland. Email: pfszwarc@uw.edu.pl.
}

\begin{abstract}
The area of Chroberz (southern Poland) poses questions of an interdisciplinary character comprising geomorphologic, sedimentation, and archaeological-historical problems. The main aim of this study was to identify the geomorphologic response to changes in the natural environment that took place in the area of the loess plateau (and its close vicinity) as a result of its settlement by man and of climate change. Periods of particularly intense human activity (land-use changes, deforestation, and agriculture) were recorded as changes in the type of sedimentation, i.e. organic sedimentation substituted for mineral one; it was extremely intensive during the Neolithic Age, Iron Age, and Early Middle Ages. The conducted fieldwork research, analysis of available archaeological materials, and radiocarbon dating results show that there is a direct connection between human economic activity in primeval and historic times and between soil erosion and accumulation of colluvial/alluvial fans in the surroundings of the locality of Chroberz. ${ }^{14} \mathrm{C}$ dates documenting the age of colluvial sediment formation show that individual areas of the upland were settled by humans asynchronously. On the basis of a low facial variability, or, occasionally, even homogeneity, of individual colluvia (from soil erosion) and their considerable thickness, it can be concluded that the land was in constant use or that the intervals with no human activity were relatively short. The progressing human impact process is visible both in the form progradation recorded as the changes in ${ }^{14} \mathrm{C}$ ages (e.g. from $1440 \pm 100$ to $780 \pm 80 \mathrm{BP}$ ) and in textural (e.g. chemical) features of sediments of which the examined fans are composed.
\end{abstract}

\section{INTRODUCTION}

The Holocene, and in particular its younger periods (i.e. Subboreal and Subatlantic), distinguishes itself from other periods in Earth's history by the economic activity of the man. Man's activity in the natural environment became a new, exceptional morphogenetic factor whose force affecting both the animate and inanimate nature is dependent upon the level of development and type of dominating economy. A widely conceived pressure caused by human activity interferes with natural transformations (e.g. climatic ones), and therefore the data complex indicating the existence in the natural environment of these 2 groups of factors has a hybrid character and it is difficult to separate them from each other. The existence of these interrelations can be deduced from the outcome of numerous studies based both on an analysis of direct measurements (the last 200-300 yr) and on indirect analyses based on a signal recorded, for instance, in lake and deep-sea sediments, corals, calcareous tufa, or ice cores, projecting changes taking place in the entire Quaternary or solely Late Glacial and Holocene periods (e.g. Boryczka 1993; Ralska-Jasiewiczowa 1993; Starkel 1999, 2001, 2005b; Alley 2000; Wagner and Melles 2002; Gerdes et al. 2003; Zolitschka et al. 2003; Vlag et al. 2004).

The loessic plateaus of southern Poland are among the territories very intensely colonized since the Neolith and have been used almost constantly ever since. Due to the long-term presence in those areas of farmers and breeders (with metallurgic cultures and their industrial activity added at a later time) together with a complex of natural and anthropogenic changes in the sediments and landforms, these areas have been of significant interest for archaeological and geomorphologic studies (Dąbrowska 1965; Śnieszko 1985, 1995; Cabaj and Nowak 1986; Maruszczak 1986; Aleksandrowicz 1987; Jersak and Śnieszko 1987; Kruk 1987; Śnieszko and Grygierczyk 1991; Kruk et al. 1996; Kalicki 1997, 2000; Tunia 1997; Andrzejewski et al. 1998; Kulczycka-Leciejewiczowa 2002; Klimek 2002; Klimek et al. 2003; Zgłobicki et al. 2003; Bałaga and Taras 2005; Łanczont and Wojtanowicz 2005; Nogaj-Chachaj et al. 2005; Starkel 2005a; Schmitt et al. 2006, Kalińska 2006; Zoll-Adamikowa et al. 2007). 

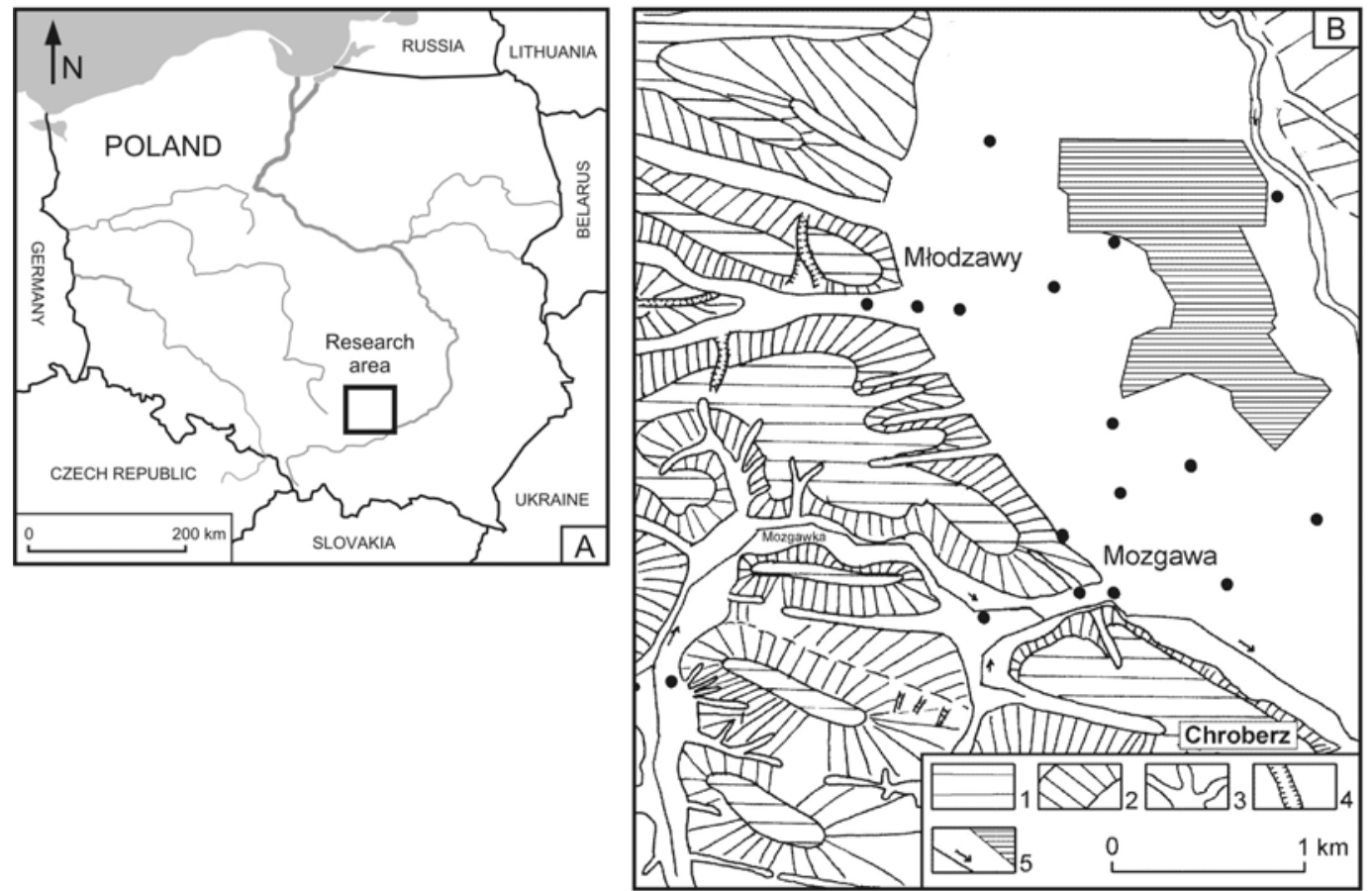

Figure 1 A) Location of the study area. B) Geomorphology of the study area. 1-top of the loess or loess and rock plateau, 2-slopes, 3-valley bottoms, 4-selected gullies, 5-surface waters (rivers and reservoirs); dots—boreholes, sampling points.

Interdisciplinary research of loessic fluvial and slope environments indicates the existence of an elementary relationship between economic activity in the past and the typological diversity of the landforms and sediments that fill valley bottoms-both dry and permanently drained (Śnieszko 1985, 1995; Maruszczak 1986; Jersak and Śnieszko 1987; Kalicki 1997, 2000; Śnieszko and Grygierczyk 1991; Klimek 2002; Schmitt et al. 2003, Zgłobicki et al. 2003; Nalepka 2005; Kalińska 2006). Changes in the texture, structure, and geochemistry of the sediments from which accumulation forms are made correlate with former intensity of human activity such as farming or deforestation. The palynological, geomorphologic, and geochemical data represent the record of human impact due to primitive Neolithic farming or breeding, Bronze and Iron Age metallurgy, and 19-20th century industrialization (e.g. Schmitt et al. 2003, 2006; Nalepka 2005; Smolska 2007; Zgłobicki and Rodzik 2007; Dotterweich 2008).

This study was conducted with a view to identify the geomorphologic response to changes in the natural environment that took place in the area of the loess plateau (and its close vicinity) as a result of its settlement by man and of climate change.

\section{RESEARCH AREA}

The loess plateaus of the Wodzisław Hummock (Kondracki 2001; see Figures 1 and 2) and also those of the surrounding areas (Miechów Upland and Proszowice Plateau) belong to areas that were systematically settled from ancient times. Archaeological as well as geological-geomorphological (or malacological) studies indicate that a considerable part of the area must have been deforested as early as the Neolithic period (Śnieszko 1985, 1995; Aleksandrowicz 1987; Kruk 1987, 1997; Jersak 


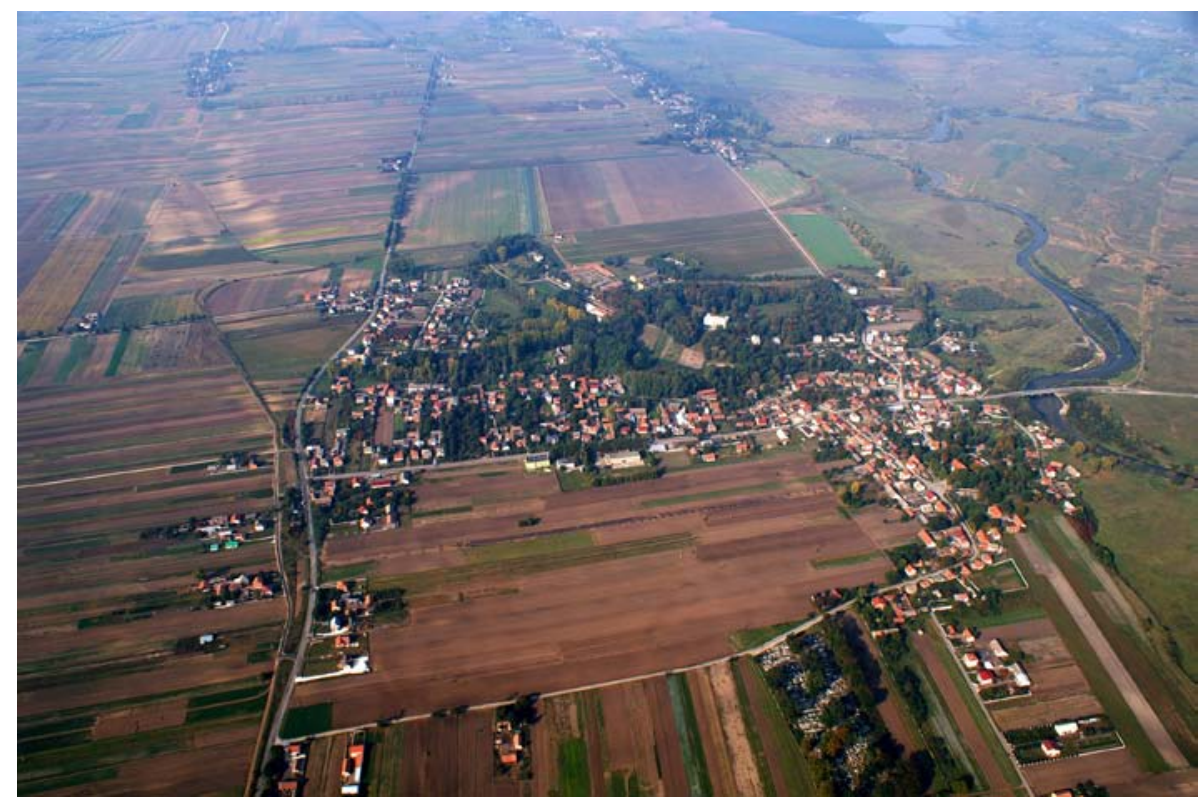

Figure 2 Aerial photograph of Chroberz, Mozgawa, and Młodzawy areas (visible fish ponds in the Nida River valley). Photo by Krystian Trela.

and Śnieszko 1987; Śnieszko and Grygierczyk 1991; Kruk et al. 1996; Kulczycka-Leciejewiczowa 2002). This is indicated by the ample inventory of archaeological sites (Project of Archaeological Picture of Poland with special archaeological site record cards, sheets 94-62 and 95-62; Dobrzańska 1987; Rydzewski 1987) and by humus horizons of buried soils found here (see Figure 3). Another proof of an early colonization of this area is the significant thickness of colluvial and proluvial (alluvial) deposits found at the slope feet, at the outlets of dry valleys, and those that were occasionally or systematically drained. Those sediments (covering peat and organic silt) rhythmically layered in numerous sites indicate periodical changes in preferences of using specific parts of the catchment area, and changes in climate (e.g. Śnieszko and Grygierczyk 1991; Śnieszko 1995; Michno 2004). Fertile soils found in these areas were extremely attractive for emerging agricultural cultures. Archaeological research indicates that the first farmers and breeders (the engraved ribbon ceramics culture) may have arrived in this region as early as $7000 \mathrm{yr}$ ago and probably since then these areas have been nearly constantly used by man. The archaeologically documented presence of man in this region should be related to the Neolithic cultures Funnel Beaker and Globular Amphora, the Lusatian culture from the Bronze Age, and the Przeworsk culture from the Iron Age. Human settlement started in the early medieval period and since then has been stable up to now (Project of Archaeological Picture of Poland with special archaeological site record cards, sheets 94-62 and 95-62; Dąbrowska 1965; Tunia 1997).

Wodzisław Hummock loesses were accumulated in the Late Pleistocene, most frequently directly on Cretaceous marl (or its weathering products), on top of southern Poland glaciation boulder-clay residue, or on fluvioperiglacial sediments (Łyczewska 1972; Cabaj and Nowak 1986; Rutkowski 1986; Tsermegas et al. 2000). Climate changes and progressive human impact (anthropopression, i.e. human-related disturbances) on loess uplands resulted in the formation and facial differentiation of sediments accumulated at the slope foot and those filling valley bottoms (e.g. Śnieszko 1985, 1995; Maruszczak 1986; Śnieszko and Grygierczyk 1991; Aleksandrowicz 1997; Kalicki 1997, 2000; Klimek 2002; Klimek et al. 2003; Zgłobicki et al. 2003; Michno 2004). 


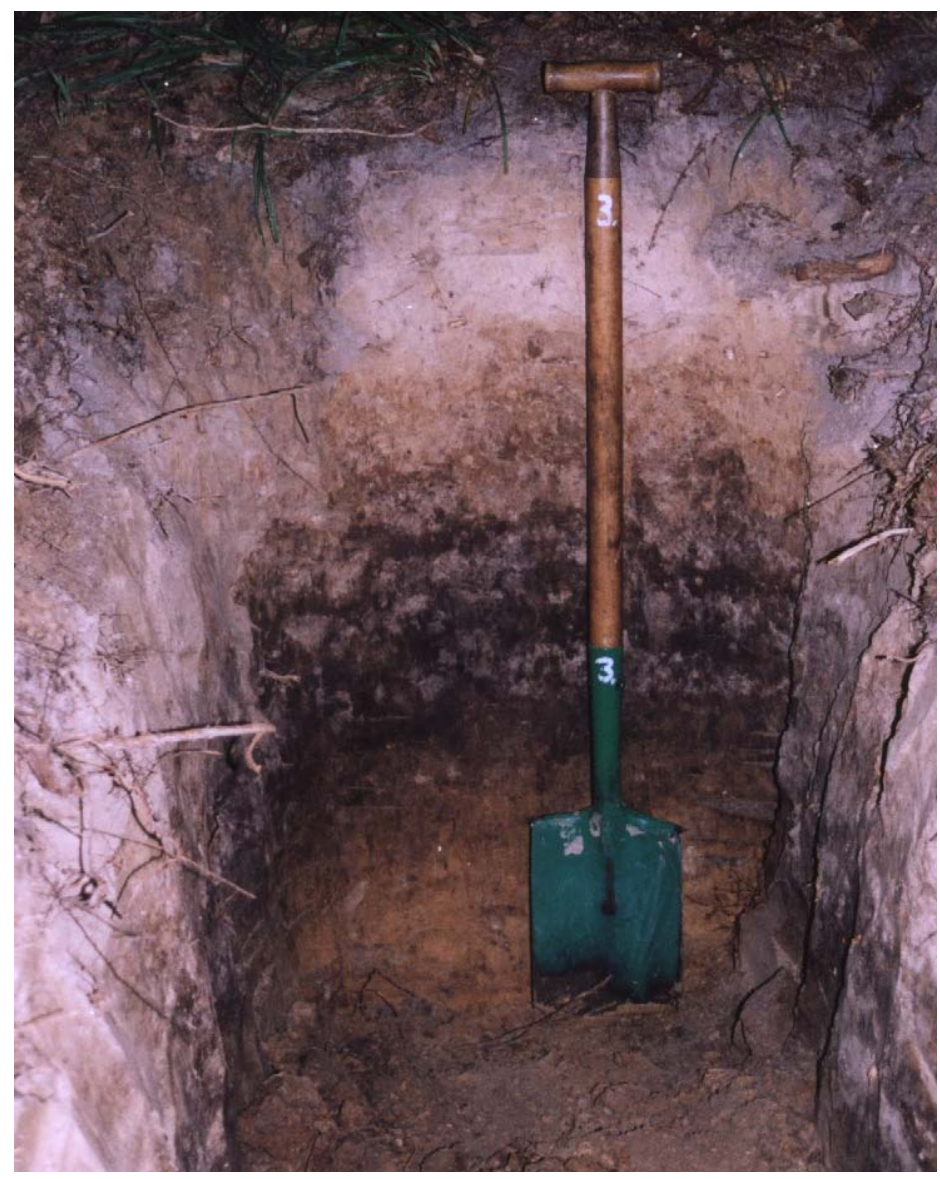

Figure 3 Humus horizon of fossil soil formed on loess deposits (top of the Wodzisław Hummock, near Wola Chroberska).

\section{MATERIALS AND METHODS}

Research in the area of Chroberz has an interdisciplinary character and comprises geomorphologic, sedimentation, and archaeological-historical problems. Research was especially intense in the years 1999-2006. Preliminary results have recently been published in Polish (Szwarczewski 2007). Field investigations included geomorphologic mapping and drilling. Slope foot and alluvial fan areas were identified by a dense network of probes and drillings. In total, 17 probing augers were made, ranging from 2 to $12 \mathrm{~m}$ of depth, from which over 300 samples of deposits were extracted for various analyses (e.g. grain size, chemical). The age of organic sediments found below colluvia and alluvia (linked to soil erosion), determined by the radiocarbon method, enabled the determination of primeval and historic soil erosion and the rate of progradation of alluvial fans.

Samples were taken by means of Eijkelkamp samplers (hand and percussion drilling sets). Conventional ${ }^{14} \mathrm{C}$ dating was carried out in the Kiev Radiocarbon Laboratory. Peat and soil organic matter were dated there (the results are presented in Table 1). Dates were calibrated using OxCal v 3.9 software (confidence level $2 \sigma$; Bronk Ramsey 1995, 2001) and the IntCal04 atmospheric data (Reimer et al. 2004). ${ }^{14} \mathrm{C}$ dating results on the main elements of surface relief are presented in Figures 4 and 5. Archaeological data available for this region have been analyzed (e.g. Tunia 1997). 
Table $1{ }^{14} \mathrm{C}$ dating of samples taken from the Chroberz area (Figure 2).

\begin{tabular}{lcll}
\hline Sample nr & ${ }^{14}$ C age & Calibrated age $(2 \sigma)$ & Material \\
\hline Ki-12424 & $1440 \pm 100$ BP & AD 390-810 (95.4\%) & peat \\
Ki-12425 & $1050 \pm 80$ BP & AD 770-1170 (95.4\%) & peat \\
Ki-10972 & $780 \pm 80$ BP & AD 1030-1330 (90.0\%) & peat \\
& & AD 1350-1390 (5.4\%) & \\
Ki-12421 & $5890 \pm 100$ BP & $5000-4490$ BP (95.4\%) & peat \\
Ki-12431 & $4420 \pm 100$ BP & $3370-2880$ BP (95.4\%) & soil organic matter \\
Ki-10974 & $2150 \pm 120$ BP & 500 BP-AD 150 (95.4\%) & peat \\
Ki-12420 & $1780 \pm 90$ BP & AD 20-440 (95.4\%) & peat \\
Ki-10973 & $11,050 \pm 200$ BP & $11,900-11,700$ BC (1.8\%) & peat \\
& & $11,600-10,600$ BC $(93.6 \%)$ & \\
\hline
\end{tabular}

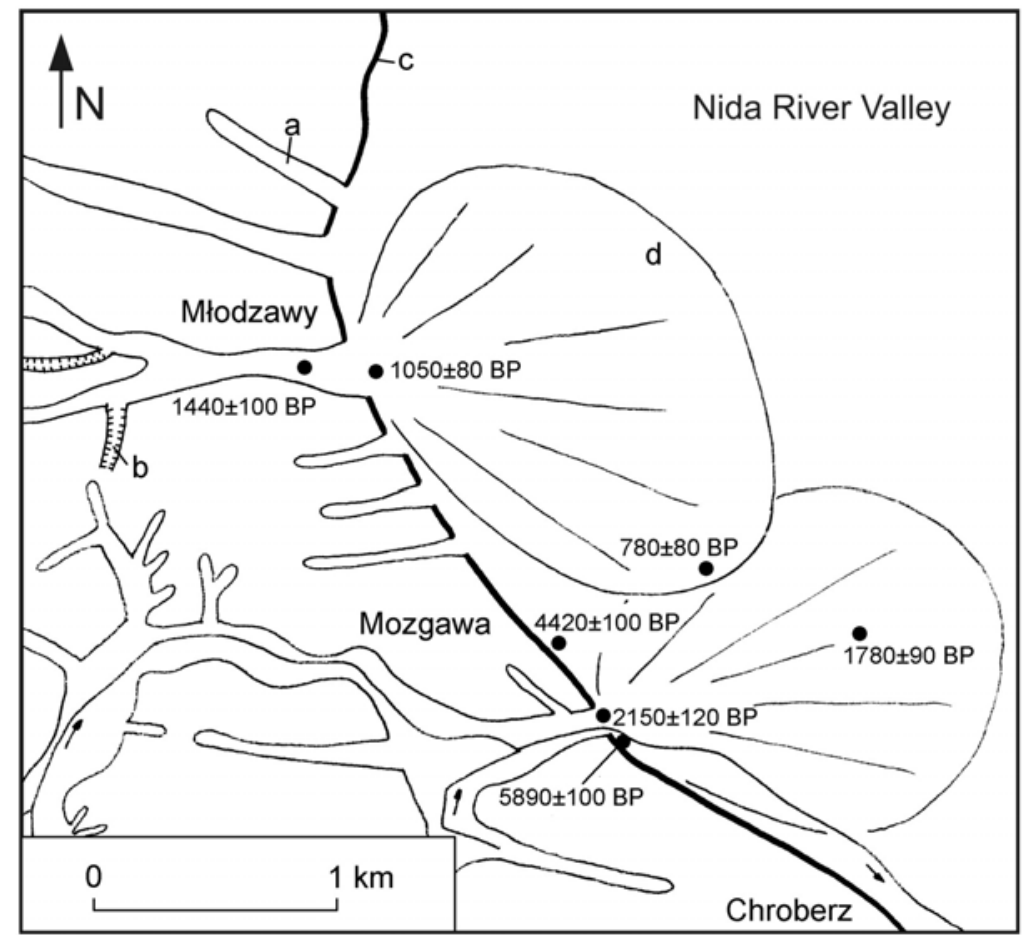

Figure 4 Alluvial fans near Mlodzawy and Mozgawa. ${ }^{14} \mathrm{C}$ ages show the stages of fan progradation and the beginning of colluvium accumulation: a-valleys; b-gullies; c-loess plateau edge; $d$-alluvial/colluvial fans.

The samples used for geochemical analyses were dried at $105^{\circ} \mathrm{C}$ and then sieved with the use of a 0.063-mm nylon sieve. A mixture of $\mathrm{HF}$ and $\mathrm{HNO}_{3}$ concentrated acids was used for the extraction in a microwave digestive system. Concentrations of trace elements ( $\mathrm{Cd}, \mathrm{Cu}, \mathrm{Pb}$, and $\mathrm{Zn}$ ) in the sediments were determined by AAS methods.

\section{RESULTS AND DISCUSSION}

The area at the edge of the Wodzisław Hummock is thickly cut with a system of dry valleys and gullies (see Figures 1 and 4). Dry valleys were formed in periglacial conditions of the last glaciation and their bottoms are filled with colluvia from soil erosion, which are locally more than $3-5 \mathrm{~m}$ thick. 


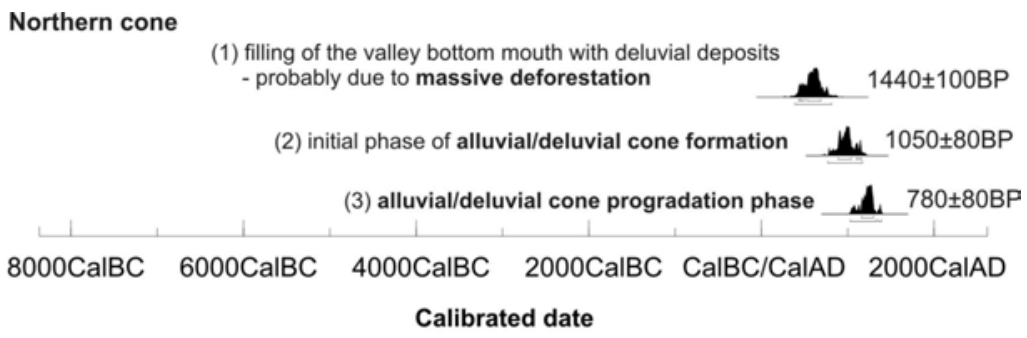

Southern cone

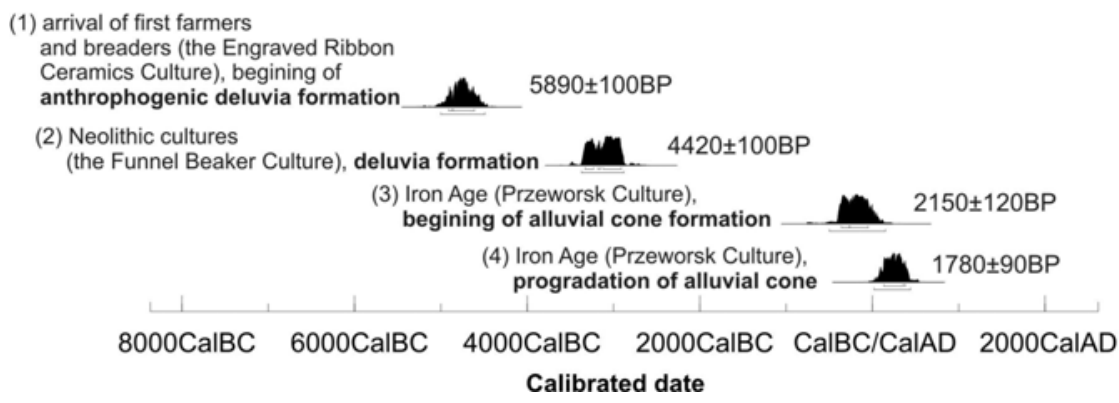

Figure 5 Calibration of ${ }^{14} \mathrm{C}$ dates (see Figure 4) of dominating geomorphic processes and sediment origin (OxCal v 3.9; Bronk Ramsey 1995, 2001).

In the bottom section, there are mineral sediments, usually of low thickness ( $\sim 0.5 \mathrm{~m})$, their granulometrical composition being similar to that of loess, sometimes with streaks of iron and manganese oxide and hydroxide precipitations. They were accumulated on (likely, fluvioperiglacial) sands, clay residue, or weathered parts of Cretaceous marl, most probably as late as in the Late Glacial period and simultaneously or just following completion of loess accumulation process. These sediments cover the Holocene colluvia, occasionally separated by buried soils; they are distinguished by the presence of humus, dispersed or accumulated in situ. The sediments accumulated in the Holocene have much greater thicknesses and they were predominantly formed as a result of primeval or historical soil erosion. They were formed in many ways: some are rhythmically layered, and they may be composed of recurrent mineral and mineral-organic levels of considerable thickness $(0.5-0.6 \mathrm{~m})$, or they represent nearly homogenous mineral-organic level reaching 1-2 $\mathrm{m}$ in thickness and more. Colluvia from the erosion of loess upland slopes coming down to the bottom of the Nida River accumulated on peat or boggy soil, and due to this, it is possible to determine the beginning date of their accumulation (by ${ }^{14} \mathrm{C}$ dating the shift in sedimentation type).

At the outlet of an eroded form coming down the Wodzisław Hummock to the Nida River valley, alluvial (alluvial-colluvial) fans were formed. Two of them are situated near each other and the area of each exceeds $1 \mathrm{~km}^{2}$. The first one (the northern one, Młodzawski), located near Młodzawy, formed at the outlet of a dry, large, flat-bottomed valley. The other (the southern one, Mozgawski), situated near the village of Mozgawa, is connected with Nida's small tributary, the Mozgawka (Figures 1 and 4). The volume of the building material of the alluvial fans is many times smaller than the size of the eroded forms, which leads to the conclusion that the valleys are older (from the Pleistocene, with foundations from the early Neogene) than the fans. Probably, at their initial formation stages part of the material may have been transported directly to the Nida River bed. In a later period (late Holocene), the tiniest fractions may have been transported in suspended matter at considerable distances and may have accumulated away from the fan. 
From the conducted fieldwork research, an analysis of available archaeological materials (Project of Archaeological Picture of Poland with special archaeological site record cards, sheets 94-62 and 9562; Tunia 1997) and ${ }^{14} \mathrm{C}$ dates, it appears that there is a direct connection between human economic activity in primeval and historic times and between soil erosion and accumulation of colluvial/alluvial fans in the surroundings of Chroberz. ${ }^{14} \mathrm{C}$ dates that document the age of colluvial sediment formation show that individual parts of the upland were settled by humans asynchronously (see Figures 4 and 5). On the basis of low facial variability, or occasionally even homogeneity, of individual colluvia series and their considerable thickness, it can be concluded that the land was in constant use or at least that the intervals with no human activity were relatively short.

The oldest colluvia dated ( $5890 \pm 100 \mathrm{BP}$ ) were determined in the southern part of the research area and are most probably related to agricultural activity of the Neolithic culture of engraved ribbon ceramics (see Figures 4 and 5). There are 2 sites belonging to that culture recognized in the Project of Archaeological Picture of Poland with special archaeological site record cards, sheet 94-62. Slightly younger colluvia are connected with agricultural activity of the population of the funnel beaker culture (12 archaeological sites), widespread on loess areas. Their age was defined by the ${ }^{14} \mathrm{C}$ method and they were found to be coming from $4420 \pm 100$ BP (Figure 4 and 5). Primeval soil erosion on slopes, besides the change in the use of land, was enhanced by a slightly more humid climate prevailing in those times (Starkel 1999; Barber and Charman 2005).

In the Roman period (the Iron Age), the research area was occupied by the Przeworsk culture population (14 archaeological sites, Project of Archaeological Picture of Poland with special archaeological site record cards, sheets 94-62 and 95-62; Dobrzańska 1997). A considerable part of the areas situated both on the loess upland and in the drier places of the valley bottom is under agricultural use. Most probably, it is then that the "Mozgawski" fan situated in the southern part began to form. The progrades towards the east and its development is documented by ${ }^{14} \mathrm{C}$ dates: $2150 \pm 120$ $\mathrm{BP}$ (in the proximal part) and $1780 \pm 90 \mathrm{BP}$ (in the distal part). The initial development phase and further progradation of the fan were preceded by the filling of the upper and central sections of the bottom of the Mozgawka River valley with colluvia and alluvia. Drillings performed at the bottom of the Mozgawka Valley and the analysis of ordinates of facial changes indicate that still in the Late and Middle Holocene the surface water efflux along the Mozgawka River valley to the Nida River was hindered or even impossible.

In the Early Medieval period, Slavic people settled in the surroundings of Chroberz. The settlement network then stabilizes - sites such as Stradów, Wiślica, and Chroberz are formed (Dąbrowska 1965; Tyniec-Kepińska 1997; Zoll-Adamikowa et al. 2007). The population increased and so did the area of agriculturally cultivated soil. There have been recorded 26 early medieval sites and 26 medieval sites in this area (Project of Archaeological Picture of Poland with special archaeological site record cards, sheet 94-62). An alluvial fan, the Młodzawski one, begins to form as a result of intensified soil erosion, which occurs in connection with the change in land use. This phenomenon, just as in the case of the southern fan, is preceded by the filling of a dry valley bottom with colluvia/alluvia. This valley-filling process starts about $1440 \pm 100$ BP (see Figures 4 and 5) and, besides increasingly marked human impact, it may be also related to a more humid climate phase. From $1050 \pm 80 \mathrm{BP}$, the proper fan formation takes place (Figure 6). The progradation process progresses very fast. At about $780 \pm 80 \mathrm{BP}$, the fan occupied the area similar to its contemporary size and only the thickness of its sedimentation layers changed. Currently, its thickness is quite significant and amounts to 2-3 $\mathrm{m}$ (in the proximal area) and up to $0.5-1 \mathrm{~m}$ (in the distal area).

The progressing human impact process can also be seen in geochemical features of sediments forming the fans referred above. A pilot study conducted on samples collected from drillings at the north- 


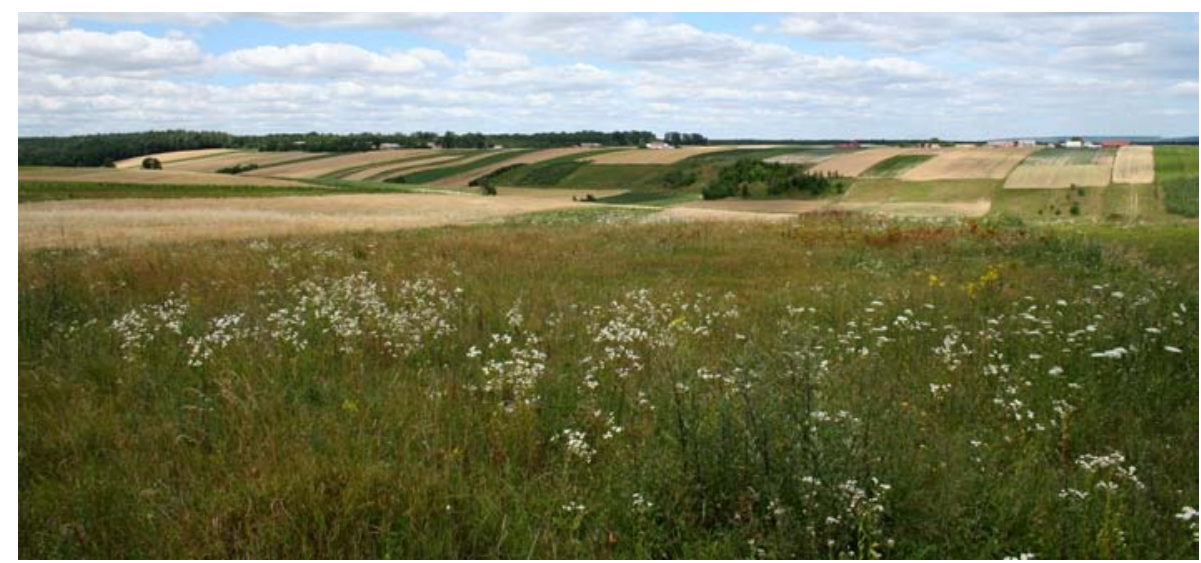

Figure 6 A wide dry valley in the vicinity of Młodzawy

ern fan outlet shows that there were a number of periods in which the accumulated sediments were enriched in such heavy metals such as $\mathrm{Cd}, \mathrm{Cu}, \mathrm{Pb}$, and $\mathrm{Zn}$ (see Figure 7). The oldest of them should be related to natural processes, i.e. the Late Glacial-Holocene transition-a period of intensified erosion and hypergenesis (the peat in the floor part was dated back to $11050 \pm 200 \mathrm{BP}$ ). Successive peaks documenting enrichment in trace elements found at depths of 1-3 $\mathrm{m}$, are most probably connected with metallurgy from the Bronze Age and Iron Age (Roman period). There is no ${ }^{14} \mathrm{C}$ dating for this part of the profile (borehole), but it can be correlated with the above-mentioned archaeological periods on the assumption that the rate of sedimentation was relatively constant, and taking into account the documented metallurgic activity of the man. The increased levels of heavy metals in the surface layers are connected with the colluvial/alluvial sediments (which started in $1050 \pm 80 \mathrm{BP}$ ) and are an effect of historic and contemporary human impact (anthropopression) - particularly intense since the Industrial Revolution and after the Second World War.

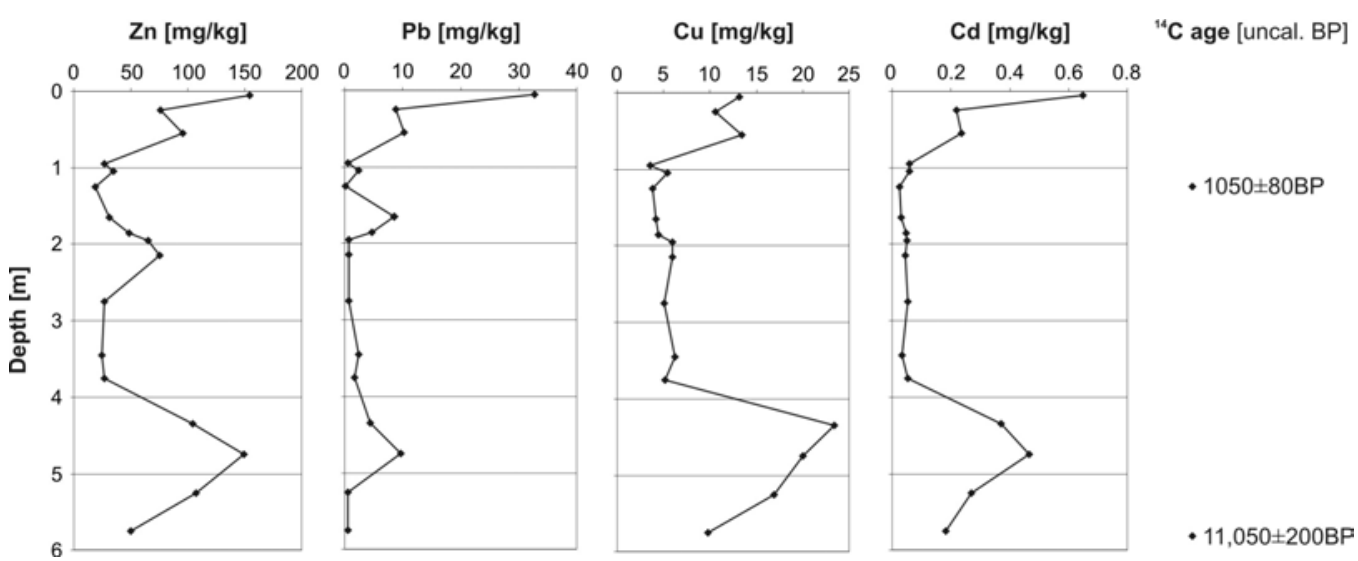

Figure $7 \mathrm{Zn}, \mathrm{Pb}, \mathrm{Cu}$, and $\mathrm{Cd}$ contents in the samples taken from the borehole in the northern fan outlet (see Figure 4)

\section{CONCLUSIONS}

A cause-and-effect relationship was determined between human economic activity, the formation of gullies (valleys) or fans, and the sediment types accumulated in the contact area between the Wodzisław Hummock loess upland and the valley of the Nida River. Periods of particularly intense 
human activity are recorded as changes in the type of sedimentation (organic sedimentation was substituted for mineral sedimentation), and their age very well correlates with available archaeological data (the Neolithic, Iron Age, and Early Middle Ages) as well as with geochemical features.

\section{REFERENCES}

Alley RB. 2000. The Younger Dryas cold interval as viewed from central Greenland. Quaternary Science Reviews 19(1-5):213-26.

Aleksandrowicz SW. 1987. Malakofauna późnego vistulianu i holocenu Środkowej cześci Wyżyny Małopolskiej. In: Wybrane zagadnienia paleogeografii czwartorzedu-holocen. Uniwersytet Śląski.

Andrzejewski A, Kajzer L, Lewandowski M. 1998. Sprawozdanie $\mathrm{z}$ archeologicznych badań ratowniczych prowadzonych w 1998 roku w Chrobrzu, gm. Złota Pińczowska, woj. Kieleckie, na stanowisku zwanym “Zamczysko.” Łódzkie Sprawozdania Archeologiczne IV:119-38.

Bałaga K, Taras H. 2005. Rozwój osadnictwa pradziejowego w północno-wschodniej cześci Kotliny Sandomierskiej na tle przemian szaty roślinnej. In: Archeologia Kotliny Sandomierskiej. Rocznik Muzeum Regionalnego. p 77-96.

Barber KE, Charman D. 2005. Holocene paleoclimate records from peatlands. In: Mackay A, Battarbee A, Birks J, Oldfield F, editors. Global Change in the Holocene. London: Hodder Arnold. p 210-26.

Boryczka J. 1993. Naturalne i antropogeniczne zmiany klimatu Ziemi w XVII-XXI wieku. Wydawnictwa WGiSR UW, Warsaw.

Bronk Ramsey C. 1995. Radiocarbon calibration and analysis of stratigraphy: the OxCal program. Radiocarbon 37(2):425-30.

Bronk Ramsey C. 2001. Development of the radiocarbon program. Radiocarbon 43(2A):355-63.

Cabaj W, Nowak WA. 1986. Rzeźba Niecki Nidziańskiej. Studia ODF XIV:119-209.

Dąbrowska E. 1965. Studia nad osadnictwem wczesnośredniowiecznym Ziemi Wiślickiej. Wrocław-Warsaw-Kraków. Z. N. im. Ossolińskich.

Dobrzańska H. 1997. Kultura przeworska w okresie rzymskim. In: Tunia K, editor. $Z$ archeologii Małopolski. Historia i stan badań zachodniomałopolskiej wyżyny lessowej. Kraków: IAiE PAN. p 331-82.

Dotterweich M. 2008. The history of soil erosion and fluvial deposits in small catchments of central Europe: deciphering the long-term interaction between humans and the environment-a review. Geomorphology 101(1-2):192-208.

Gerdes G, Petzelberger BEM, Scholz-Böttcher BM, Streif H. 2003. The record of climatic change in the geological archives of shallow marine, coastal, and adjacent lowland areas of northern Germany. Quaternary Science Reviews 22(1):101-24.
Jersak J, Śnieszko Z. 1987. Zmiany środowiska geograficznego w późnym glacjale i holocenie na obszarach lessowych Wyżyny Miechowskiej i Opatowsko-Sandomierskiej. In: Wybrane zagadnienia paleogeografii czwartorzedu-holocen. Uniwersytet Śląski.

Kalicki T. 1997. The reflection of climatic changes and human activity on sediments of small Forecarpathian tributaries of the Vistula river near Cracow, Poland. Studia Geomorphologica Carpatho-Balcanica 31: 129-41.

Kalicki T. 2000. The sediments of small Forecarpathian rivers near Cracow and Przemyśl (Poland): climate and human impact. In: Balteanu D, Ielenicz M, Popescu N, editors. Geomorphology of the Carpatho-Balcan Region. Bucharest: Corint.

Kalińska E. 2006. Formy antropogeniczne i ich wpływ na kształtowanie rzeźby w obszarach lessowych na przykładzie zlewni Kwaskowa Góra, Kazimierz Dolny. In: Latocha A, Traczyk A, editors. Zapis działalności człowieka w Środowisku przyrodniczym. Metody badań i studia przypadków. Wrocław: Wyd. GAJT.

Klimek K. 2002. Zapis pradziejowej i historycznej erozji gleb w deluwiach i aluwiach górnośląskiej cześci dorzecza Odry. In: Smolska E, Szwarczewski P, editors. Zapis działalności człowieka w środowisku przyrodniczym. Volume 1. Warsaw-Łomża: WGSR UW, WSA.

Klimek K, Łanczont M, Nogaj-Chachaj J. 2003. Aluwiacja małych dolin w obrebie przykarpackiej wysoczyzny lessowej jako wskaźnik zmian użytkowania ziemi w ostatnim 1000-leciu. In: Waga JM, Kocel K, editors. Człowiek w środowisku przyrodniczym-zapis działalności. Sosnowiec: Uniwersytet Śląski. p 84-9.

Kondracki J. 2001. Geografia Regionalna Polski. Warsaw: Wydawnictwo Naukowe PWN.

Kruk J. 1987. Wczesne rolnictwo i jego wpływ na kształtowanie środowiska naturalnego wyżyn lessowych dorzecza górnej Wisły. In: Wybrane zagadnienia paleogeografii czwartorzedu-holocen. Uniwersytet Śląski.

Kruk J. 1997. Zarys fizjografii. In: Tunia K, editor. Z archeologii Małopolski. Historia i stan badań zachodniomałopolskiej wyżyny lessowej. Kraków: IAiE PAN. p 11-56.

Kruk J, Milisauskas S, Aleksandrowicz SW, Śnieszko Z. 1996. Osadnictwo i zmiany środowiska naturalnego wyżyn lessowych. In: Studium archeologiczne i paleogeograficzne nad neolitem $w$ dorzeczu Nidzicy. Kraków: IAiE PAN. 
Kulczycka-Leciejewiczowa A. 2002. Zawarża. Osiedle neolityczne $w$ południowopolskiej strefie lessowej. Wrocław: IAiE PAN.

Łanczont M, Wojtanowicz J. 2005. Uwarunkowania przyrodnicze rozwoju osadnictwa pradziejowego w Kotlinie Sandomierskiej. In: Archeologia Kotliny Sandomierskiej. Rocznik Muzeum Regionalnego. p 39-55.

Łyczewska J. 1972. Objaśnienia do Szczegółowej Mapy Geologicznej Polski 1 : 50 000, ark. Busko Zdrój. Warsaw: PIG.

Maruszczak H. 1986. Tendencje sekularne i zjawiska ekstremalne w rozwoju rzeźby małopolskich wyżyn lessowych w czasach historycznych. Czasopismo Geograficzne 57(2):271-81.

Michno A. 2004. Transformacja doliny dolnej Nidzicy w holocenie. Kraków: IGiGP UJ.

Nalepka D. 2005. Late Glacial and Holocene palaeoecological conditions and changes of vegetation cover under early farming activity in the south Kujawy region (Central Poland). Acta Palaeobotanica (Supplement) 6:3-90.

Nogaj-Chachaj J, Klimek K, Łanczont M. 2005. Pradziejowe osadnictwo wschodniej cześci Kotliny Sandomierskiej w aspekcie rozwoju dna doliny Sanu w okolicy Stubna. In: Archeologia Kotliny Sandomierskiej. Rocznik Muzeum Regionalnego. p 57-76.

Project of Archaeological Picture of Poland with special archaeological site record cards, sheets 94-62, 95-62.

Ralska-Jasiewiczowa M, editor. 1993. Jezioro Gosciążstan badań nad osadami dennymi i środowiskiem współczesnym. Materiały spotkania roboczego w Gliwicach 30.03-02.04.1992. Polish Botanical Studies 8.

Reimer PJ, Baillie MGL, Bard E, Bayliss A, Beck JW, Bertrand CJH, Blackwell PG, Buck CE, Burr GS, Cutler KB, Damon PE, Edwards RL, Fairbanks RG, Friedrich M, Guilderson TP, Hogg AG, Hughen KA, Kromer B, McCormac G, Manning S, Bronk Ramsey C, Reimer RW, Remmele S, Southon JR, Stuiver M, Talamo S, Taylor FW, van der Plicht J, Weyhenmeyer CE. 2004. IntCal04 terrestrial radiocarbon age calibration, 0-26 cal kyr BP. Radiocarbon 46(3):1029-58.

Rutkowski J. 1986. Budowa geologiczna Niecki Nidziańskiej. Studia ODF XIV: 35-61.

Rydzewski J. 1997. Kultura łużycka. In: Tunia K, editor. Z archeologii Małopolski. Historia i stan badań zachodniomatopolskiej wyżyny lessowej. Kraków: IAiE PAN. p 245-86.

Schmitt A, Dotterweich M, Schmidtchen G, Bork HR. 2003. Vineyards, hopgardens and recent afforestation: effects of late Holocene land use change on soil erosion in northern Bavaria, Germany. Catena 51:241-54.

Schmitt A, Rodzik J, Zgłobicki W, Russok Ch, Dotterweich M, Bork HR. 2006. Time and scale of gully erosion in the Jedliczny Dol gully system, south-east Poland. Catena 68:124-32.

Smolska E. 2007. Development of gullies and sediment fans in last-glacial areas on the example of the Suwałki Lakeland (NE Poland). Catena 71:122-31.

Śnieszko Z. 1985. Paleogeografia holocenu $w$ dolinie Sancygniówki. Acta Geographica Lodziensia 51.

Śnieszko Z. 1995. Ewolucja obszarów lessowych Wyżyn Polskich w czasie ostatnich 15000 lat. Katowice: Wydawnictwa Uniwersytetu Śląskiego.

Śnieszko Z, Grygierczyk S. 1991. Osady kopalnej bruzdy w Bronocicach i ich związek z działalnością człowieka w neolicie. In: Jersak J, editor. Less i osady dolinne. Katowice: Wydawnictwa Uniwersytetu Śląskiego. p 129-46.

Starkel L, editor. 1999. Geografia Polski. środowisko przyrodnicze. Warsaw: Wydawnictwo Naukowe PWN.

Starkel L. 2001. Historia doliny Wisty od ostatniego zlodowacenia do dziś. Warsaw: IGiPZ PAN, Monografie.

Starkel L. 2005a. Typy rzeźby Kotliny Sandomierskiej i ich rola w kształtowaniu osadnictwa (wprowadzenie do sesji: Środowiskowe uwarunkowania osadnictwa pradziejowego w Kotlinie Sandomierskiej). In: Archeologia Kotliny Sandomierskiej. Rocznik Muzeum Regionalnego. p 11-7.

Starkel L. 2005b. Anthropogenic soil erosion since the Neolithic in Poland. Z. Geomorphol. N.E. (Suppl.) 139:189-201.

Szwarczewski P. 2007. Geomorfologiczne skutki zasiedlenia wysoczyzn lessowych na przykładzie okolic Chrobrza (Ponidzie Pińczowskie). In: Smolska E, Giriat D, editors. Rekonstrukcja dynamiki procesów geomorfologicznych - formy rzeźby i osady. Warsaw: Uniwersytet Warszawski.

Tsermegas I, Szwarczewski P, Woronko B, Recielski K, Rojan E. 2000. Ewolucja i dynamika rzeźby okolic Pińczowa. Prace i Studia Geograficzne 27:11-42.

Tunia K, editor. 1997. Z archeologii Matopolski. Historia i stan badań zachodniomatopolskiej wyżyny lessowej. Kraków: IAiE PAN.

Tyniec-Kepińska A. 1997. Wczesne średniowiecze. In: Tunia K, editor. $Z$ archeologii Małopolski. Historia i stan badań zachodniomałopolskiej wyżyny lessowej. Kraków: IAiE PAN. p 383-408.

Vlag PA, Kruiver PP, Dekkers MJ. 2004. Evaluating climate change by multivariate statistical techniques on magnetic and chemical properties of marine sediments (Azores region). Palaeogeography, Palaeoclimatology, Palaeoecology 212:23-44.

Wagner B, Melles M. 2002. Holocene environmental history of western Ymer Ø, East Greenland, inferred from lake sediments. Quaternary International 89: 165-76.

Zgłobicki W, Rodzik J. 2007. Heavy metals in the slope deposits of loess areas of the Lublin Upland (E Poland). Catena 71:84-95.

Zgłobicki W, Rodzik J, Schmitt A, Schmidtchen G, Dotterweich M, Zamhofer S, Bork H-R. 2003. Fazy erozji 
wawozowej w okolicach Kazimierza Dolnego. In: Waga JM, Kocel K, editors. Człowiek w środowisku przyrodniczym—zapis działalności. Sosnowiec: Uniwersytet Śląski. p 234-8.

Zolitschka B, Behre KE, Schneider J. 2003. Human and climatic impact on the environment as derived from colluvial, fluvial and lacustrine archives-examples from the Bronze Age to the Migration period, Germany. Quaternary Science Reviews 22(1):81-100.

Zoll-Adamikowa H, Szmoniewski BSz, TyniecKepińska A, Wołoszyn M. 2007. Stradów-wczesnośredniowieczny zespót osadniczy. Kraków: IAiE PAN, Polskie Badania Archeologiczne. 